\title{
PERANAN SEKTOR PERTANIAN TERHADAP KESEMPATAN KERJA DI KABUPATEN BARITO SELATAN
}

\author{
THE ROLE OF THE AGRICULTURAL SECTOR \\ IN EMPLOYMENT OPPORTUNITIES \\ IN BARITO SELATAN DISTRICT \\ ${ }^{1}$ Frilia Christin, ${ }^{2}$ Betrixia Barbara, ${ }^{3}$ Evi Feronika \\ ${ }^{1}$ Alumnus Program Studi Agribisnis, Fakultas Pertanian, Universitas Palangka Raya \\ ${ }^{2,3}$ Staf Pengajar Program Studi Agribisnis, Fakultas Pertanian, Universitas Palangka Raya \\ email: barbarabetrixia@gmail.com
}

\begin{abstract}
ABSTRAK
Penelitian ini memiliki tujuan untuk mengetahui peranan sektor pertanian dalam membuka kesempatan kerja di Kabupaten Barito Selatan. Data yang digunakan adalah data sekunder. Alat analisis yang digunakan adalah angka pengganda tenaga kerja. Hasil penelitian menunjukkan bahwa angka pengganda tenaga kerja sektor pertanian di Kabupaten Barito Selatan adalah sebesar 1,6, yang berarti bahwa setiap terjadi peningkatan 1 tenaga kerja sektor pertanian, maka akan membuka kesempatan kerja sektor ekonomi lainnya di Kabupaten Barito Selatan sebanyak 1 sampai 2 tenaga kerja.
\end{abstract}

Kata kunci: Pengganda, sektor pertanian, tenaga kerja

\section{ABSTRACT}

The purpose of this study is to know the role of agricultural sector in the absorption of the Labor In South Barito Regency. The data used in this study is secondary data. To answer this purpose, used labor number multiplier, shift share, pure forecast. The result of this Study indicates that the number of labor of agricultural sector in South Barito Regency is 1.6, which means that every increase of 1 labor of agriculture sector, it will open the job opportunity of other economic sector in South Barito Regency as much as 1 to 2 labors.

Keyworlds: Agricultural sector, labor, multiplier

\section{PENDAHULUAN}

\section{Latar Belakang}

Indonesia adalah sebuah negara yang pendapatan nasional terbesar diperoleh dari sektor pertanian. Sehingga pemerintah berupaya dalam mendukung sektor pertanian seperti adanya kebijakan pemerintah yang menyediakan sarana dan prasarana yang memadai untuk pembangunan pertanian (Khaafidh, 2013). Oleh karena itu, pembangunan di sektor pertanian akan berdampak terhadap penyerapan tenaga kerja sektor pertanian itu sendiri dan sektor lainnya. selain itu, sektor pertanian diharapkan mampu menciptakan lapangan kerja yang besar untuk mengimbangi peningkatan jumlah penduduk Indonesia karena apabila jumlah penduduk lebih besar dari jumlah ketersediaan lapangan kerja yang ada maka akan menyebabkan sebagian dari penduduk yang berada pada usia kerja tidak memperoleh pekerjaan (Sulistiawati, 2012). 
Kabupaten Barito Selatan adalah kabupaten yang memiliki kemampuan yang cukup besar dalam menyerap tenaga kerja di berbagai sektor perekonomian. Tingkat penganguran lebih minim dibandingkan pekerja tetapi jumlah pengangguran tetap harus diperhatikan. Dengan demikian, diharapkan pembangunan ekonomi daerah Kabupaten Barito Selatan dapat terus meningkat. Keadaan angkatan kerja di Kabupaten Barito Selatan dapat dilihat pada Tabel 1.

Tabel 1. Jumlah Angkatan Kerja, Pekerja dan Pengangguran di Kabupaten Barito Selatan, Tahun 2012-2015

\begin{tabular}{|c|c|c|c|c|c|c|c|}
\hline No. & $\begin{array}{c}\text { Jenis } \\
\text { Kegiatan Utama }\end{array}$ & 2011 & 2012 & 2013 & 2014 & 2015 & $\begin{array}{l}\text { Rata-Rata } \\
\text { (Jiwa) }\end{array}$ \\
\hline \multirow{2}{*}{1.} & Pekerja & 62.120 & 59.478 & 59.570 & 62.079 & 57.346 & 60.120 \\
\hline & Persentase (\%) & 97,47 & 98,27 & 97,83 & 96,23 & 90,01 & 95,92 \\
\hline \multirow{4}{*}{2.} & Pengangguran & 1.609 & 1.045 & 1.322 & 2.433 & 6.363 & 2.554 \\
\hline & Persentase $(\%)$ & 2,53 & 1,73 & 2,17 & 3,77 & 9,99 & 4,08 \\
\hline & Jumlah & 63.729 & 60.523 & 60.892 & 64.512 & 63.709 & 62.674 \\
\hline & Persentase $(\%)$ & 100,00 & 100,00 & 100,00 & 100,00 & 100,00 & 100,00 \\
\hline
\end{tabular}

Sumber: Statistik Ketenagakerjaan Kalimantan Tengah, Tahun 2016.

Berdasarkan Tabel 1. jumlah pekerja di Kabupaten Barito Selatan dari tahun 2011 sampai 2015 terus mengalami fluktuasi. Tahun 2011 menunjukkan jumlah pekerja berada pada tingkat terbesar yaitu sebesar 62.120 jiwa dan pada tahun 2015 pekerja berada pada tingkat terendah yaitu sebesar 57.346 jiwa. Walau demikian jumlah pekerja lebih besar jika dibandingkan dengan tingkat pengangguran, dengan rata-rata tingkat pekerja sebesar 60.120 jiwa.

Apabila dilihat dari jumlah angkatan kerja yang didominasi oleh pekerja maka Kabupaten Barito Selatan dapat dikatakan suatu daerah yang telah dapat memanfaatkan sumberdaya manusianya dengan baik untuk masuk ke dalam sektor-sektor perekonomian sehingga mampu meningkatkan pembangunan daerah. Kabupaten Barito Selatan dengan kemampuan menyerap tenaga kerja yang lebih besar dibandingkan pengangguran tersebut berpotensi dalam mencapai kemajuan pembangunan daerah.

Penyerapan tenaga kerja sektor pertanianKabupaten Barito Selatan selama tahun 2011-2015 mencapai nilai rata-rata sebesar 38.187 jiwa. Dari tahun 2011 sampai dengan tahun 2015 sektor pertanian merupakan sektor yang unggul dalam menyerap tenaga kerja. Pada tahun 2013 merupakan tingkat penyerapan tenaga kerja terbesar yaitu sebesar 42.494 jiwa. Sedangkan pada tahun 2015 terjadi penurunan yang sangat besar sehingga pada tahun 2015 menjadi tahun dengan tingkat penyerapan tenaga kerja terendah sebesar 30.824 jiwa (Tabel 2).

Tabel 2. Penduduk Usia 15 Tahun ke Atas yang Bekerja Menurut Sektor di Kabupaten Barito Selatan, Tahun 2011 - 2015 (Jiwa)

\begin{tabular}{|c|c|c|c|c|c|c|c|}
\hline \multirow{2}{*}{ No. } & \multirow{2}{*}{ Sektor } & \multicolumn{5}{|c|}{ Tahun } & \multirow{2}{*}{$\begin{array}{c}\text { Rata-Rata } \\
\text { (Jiwa) }\end{array}$} \\
\hline & & 2011 & 2012 & 2013 & 2014 & 2015 & \\
\hline \multirow{2}{*}{1.} & Pertanian & 39.305 & 38.609 & 42.494 & 39.705 & 30.824 & 38.187 \\
\hline & Kontribusi (\%) & 63,27 & 64,91 & 71,33 & 63,96 & 53,75 & 63,52 \\
\hline 2. & $\begin{array}{l}\text { Pertambangan, } \\
\text { Energi \& } \\
\text { Kontruksi }\end{array}$ & 4.343 & 2.687 & 2.090 & 3.488 & 3.448 & 3.211 \\
\hline
\end{tabular}




\begin{tabular}{|c|c|c|c|c|c|c|}
\hline Kontribusi (\%) & 6,99 & 4,52 & 3,51 & 5,62 & 6,01 & 5,34 \\
\hline Industri & 445 & 850 & 893 & 621 & 3.090 & 1.179 \\
\hline 5. Kontribusi (\%) & 0,71 & 1,43 & 1,50 & 1,00 & 5,39 & 1,96 \\
\hline Jasa & 18.027 & 17.332 & 14.093 & 18.265 & 19.984 & 17.540 \\
\hline 4. Kontribusi (\%) & 29,01 & 29,14 & 23,66 & 29,42 & 34,85 & 29,17 \\
\hline Jumlah & 62.120 & 59.478 & 59.570 & 62.079 & 57.346 & 60.117 \\
\hline Kontribusi (\%) & 100,00 & 100,00 & 100,00 & 100,00 & 100,00 & 100,00 \\
\hline
\end{tabular}

Sumber: Badan Pusat Statistik Kabupaten Barito Selatan, Tahun 2016.

\section{Tujuan Penelitian}

Adapun tujuan penelitian ini adalah untuk mengetahui peranan sektor pertanian dalam penyerapan tenaga kerja di Kabupaten Barito Selatan. Periode waktu analisis adalah pada rentang tahun 20112015.

\section{TINJAUAN PUSTAKA}

\section{Tenaga Kerja}

Tenaga kerja menurut UndangUndang Nomor 13 Tahun 2003 adalah setiap orang yang mampu melakukan pekerjaan guna menghasilkan barang dan/atau jasa baik untuk memenuhi kebutuhan sendiri maupun untuk masyarakat. Tenaga kerja juga dapat diartikan sebagai penduduk yang berada dalam batas usia kerja. Tenaga kerja disebut juga golongan produktif (Safangatun, 2011).

Tenaga kerja diartikan sebagai penduduk usia kerja (berusia 15-64 tahun) dan disebut pula dengan manpower yang terdiri dari angkatan kerja (Amin, 2014). Angkatan kerja dan bukan angkatan kerja. Angkatan kerja adalah bagian tenaga kerja yang ingin dan yang telah benar-benar menghasilkan barang dan jasa. Angkatan kerja atau labour force terdiri dari golongan yang bekerja, dan golongan belum bekerja atau yang menganggur serta mencari pekerjaan. Bukan angkatan kerja terdiri dari golongan yang sedang bersekolah, golongan yang mengurus rumah tangga dan golongan-golongan lainnya atau penerima pendapatan. Ketiga golongan dalam kelompok bukan angkatan kerja sewaktu-waktu dapat menawarkan jasanya untuk bekerja. Sehingga kelompok ini juga sering dinamakan potensial labor force (Wicaksono, 2010).

\section{Penelitian Terdahulu}

Kurniawan (2008) dalam penelitiannya yang berjudul "Peranan Sektor Pertanian dalam Penyerapan Tenaga Kerja di Kabupaten Temanggung”, menggunakan angka pengganda tenaga kerja, diperoleh rata-rata angka pengganda tenagakerja di Kabupaten Temanggung sebesar 2,8. Artinya sektor pertanian diKabupaten Temanggung berperan dalam meningkatkan kesempatan kerja pada sektor perekonomian lainnya sebesar 2 sampai 3 orang setiap terjadi peningkatan kesempatan kerja pada sektor pertanian sebesar 1 orang.

Berdasarkan penelitian Rozi, dkk. (2017) yang berjudul "Peranan Sektor Pertanian dalam Penyerapan Tenaga Kerja di Provinsi Aceh" menunjukkan bahwa nilai rata-rata angka pengganda yang dihasilkan sebesar 1,85 dimana setiap peningkatan satu orang tenaga kerja di sektor pertanian maka terjadi peningkatan tenaga kerja hingga 1 atau 2 orang di sektor lain.

Berdasarkan penelitian Safangatun (2011) yang berjudul "Peranan Sektor Pertanian dalam Penyerapan Tenaga Kerja di Kabupaten Cilacap" untuk meneliti peranan sektor pertanian dalam penyerapan tenaga kerja di kabupaten Cilacap selama 5 tahun (2005-2009) yang di hitung dengan menggunakan angka pengganda tenaga kerja cenderung menurun. Hasil 
perhitungan angka pengganda tenaga kerja rata-rata sebesar 2,54 yang berarti bahwa setiap terjadi peningkatan tenaga kerja sebanyak 1 tenaga kerja di sektor pertanian, maka akan membuka kesempatan kerja total di Kabupaten Cilacap sebanyak 2 sampai 3 tenaga kerja.

Berdasarkan penelitian Luthfi (2017) yang berjudul "Peran Sektor Pertanian terhadap Penyerapan Tenaga Kerja dan Distribusi Pendapatan di Kabupaten Klaten" dengan menggunakan angka pengganda tenaga kerja. Rata-rata angka pengganda tenaga kerja sektor pertanian di Kabupaten Klaten dari tahun 2011-2015 adalah 1,25. Hal ini berarti setiap peningkatan satu orang tenaga kerja pada sektor pertanian dapat meningkatkan tenaga kerja secara keseluruhan di Kabuten Klaten sebanyak satu hingga dua orang.

Berdasarkan penelitian Nugroho (2015) yang berjudul "Peranan Sektor Pertanian dalam Penyerapan Tenaga Kerja di Kabupaten Kebumen" dengan menggunakan angka pengganda tenaga kerja dihasilkan rata-rata angka pengganda sebesar 1,774 yang artinya bila terjadi peningkatan kesempatan kerja di sektor pertanian sebesar satu orang akan dapat meningkatkan kesempatan kerja keseluruhan sebanyak 2 orang di wilayah Kabupaten Kebumen.

Berdasarkan penelitian Safira (2017) yang berjudul "Analisis Peranan Sektor Pertanian dalam Penyerapan Tenaga Kerja di Kabupaten Sukoharjo" dengan menggunakan angka pengganda tenaga kerja diperoleh hasil rata-rata angka pengganda tenaga kerja di Kabupaten Sukoharjo dari tahun 2006-2015 adalah 6,28 . Hal ini berarti setiap peningkatan satu tenaga kerja di sektor pertanian maka akan meningkatkan tenaga kerja di Kabupaten Sukoharjo secara keseluruhan sebanyak 6 orang.

\section{METODE PENELITIAN}

Penelitian ini dilaksanakan Kabupaten Barito Selatan dan dipilih secara purposive (sengaja). Data yang digunakan dalam penelitian ini adalah data sekunder dengan rentang waktu lima tahun, yaitu tahun 2011-2015 yang diperoleh dari Badan Pusat Statistik (BPS) Kabupaten Barito Selatan, BPS Provinsi Kalimantan Tengah dan Dinas Ketenagakerjaan dan Transmigrasi (Disnakertrans) Kabupaten Barito Selatan. Data tersebut berupa data PDRB Kabupaten Barito Selatan, data tenaga kerja Kabupaten Barito Selatan, data tenaga kerja Provinsi Kalimantan Tengah, kondisi umum Kabupaten Barito Selatan, dan data lain yang mendukung.

Untuk peranan sektor pertanian dalam dalam menciptakan kesempatan kerja Kabupaten Barito Selatan digunakan analisis angka pengganda. Menurut Budiharsono (2005), untuk menghitung besarnya peranan sektor pertanian dalam menyerap tenaga kerja adalah menggunakan angka pengganda tenaga kerja. Angka pengganda tenaga kerja diperoleh dari perbandingan antara jumlah tenaga kerja di seluruh sektor $(\mathrm{N})$ dengan jumlah tenaga kerja sektor pertanian (NB). Untuk memperoleh angka pengganda tenaga kerja Kabupaten Barsel menggunakan data lima tahun yaitu tahun 2011-2015. Adapun rumusnya adalah sebagai berikut:

$$
\mathrm{K}=\frac{N}{N}
$$

Keterangan:

$\mathrm{K}$ : pengganda tenaga kerja

$\mathrm{N}$ : jumlah tenaga kerja diseluruh sektor

NB: jumlah tenaga kerja di sektor pertanian

Angka pengganda tenaga kerja yang diperoleh, dikalikan dengan perubahan tenaga kerja di sektor pertanian akan dihasilkan angka pertumbuhan kesempatan kerja total dengan rumus:

$$
\Delta \mathrm{N}=\Delta \mathrm{NB} \times \mathrm{K}
$$

Keterangan:

$\Delta \mathrm{N}$ : pertumbuhan tenaga kerja total di Kabupaten Barito Selatan 
$\Delta \mathrm{NB}$ : pertumbuhan tenaga kerja sektor pertanian Kabupaten Barito Selatan

\section{HASIL DAN PEMBAHASAN}

Sektor pertanian merupakan sektor yang menyerap tenaga kerja terbesar di Kabupaten Barito Selatan. untuk mengetahui besarnya peranan sektor pertanian dalam menyerap tenaga kerja adalah menggunakan angka pengganda tenaga kerja. Angka pengganda tenaga kerja adalah perbandingan antara jumlah tenaga kerja seluruh sektor $(\mathrm{N})$ dengan jumlah tenaga kerja sektor pertanian (NB). Apabila telah diketahui nilai angka penggganda tenaga kerja, maka dapat diperoleh besarnya pertumbuhan tenaga kerja total wilayah Kabupaten Barito Selatan yaitu dengan cara mengalikan angka pengganda tenaga kerja yang telah diperoleh dengan pertumbuhan tenaga kerja sektor pertanian Kabupaten Barito Selatan. Hasil perhitungan angka pengganda tenaga kerja dan pertumbuhan tenaga kerja dalam kurun waktu lima tahun di Kabupaten Barito Selatan tahun 20112015 dapat dilihat pada Tabel 3.

Tabel 3. Angka Pengganda Tenaga Kerja Kabupaten Barito Selatan Tahun 2011-2015 (Jiwa)

\begin{tabular}{ccccrr}
\hline Tahun & $\begin{array}{c}\text { TK Pertanian } \\
(\mathrm{NB})\end{array}$ & $\begin{array}{c}\text { TK Total } \\
(\mathrm{N})\end{array}$ & $\mathrm{K}$ & $\Delta \mathrm{NB}$ & \multicolumn{1}{c}{$\Delta \mathrm{N}$} \\
\hline 2011 & 39.305 & 62.120 & 1,6 & - & - \\
2012 & 38.609 & 59.478 & 1,5 & -696 & $-1.072,2$ \\
2013 & 42.494 & 59.570 & 1,4 & 3.885 & $5.446,2$ \\
2014 & 39.705 & 62.079 & 1,6 & -2.789 & $-4.360,6$ \\
2015 & 30.824 & 57.347 & 1,9 & -8.881 & $-16.522,5$ \\
\hline & & Rata-Rata & 1,6 & & \\
\hline
\end{tabular}

Sumber: Data sekunder yang diolah.

Berdasarkan Tabel 3, diketahui angka pengganda tenaga kerja yang diperoleh dari hasil analisis menunjukkan terjadi perubahan, yaitu dari tahun 2011 sampai pada tahun 2013 cenderung menurun, sedangkan dari tahun 2013 sampai pada tahun 2015 cenderung meningkat. Tahun 2011 nilainya sebesar 1,6 dan terjadi penurunan tahun 2012 nilainya sebesar 1,5 dan terus menurun sampai pada tahun 2013 nilainya sebesar 1,4. Kemudian terus meningkat pada 2014 dengan nilai sebesar 1,6 hingga tahun 2015 dengan nilai sebesar 1,9. Nilai rata-rata angka pengganda tenaga kerja yang diperoleh yaitu sebesar 1,6 yang berarti bahwa selama tahun 2011-2015 setiap terjadi peningkatan 1 tenaga kerja sektor pertanian, maka akan membuka kesempatan kerja sektor ekonomi lainnya di Kabupaten Barito Selatan sebanyak 1 sampai 2 tenaga kerja.
Rata-rata angka pengganda tenaga kerja dalam penelitian ini tidak jauh berbeda dengan rata-rata hasil penelitian yang dilakukan oleh Rozi, dkk. (2017) di Provinsi Aceh dengan hasil rata-rata angka pengganda tenaga kerja sebesar 1,85, Luthfi (2017), di Kabupaten Klaten dengan hasil rata-rata angka pengganda tenaga kerja sebesar 1,25 dan Nugroho (2015) di Kabupaten Kebumen dengan hasil rata-rata angka pengganda tenaga kerja sebesar 1,774. Melalui beberapa penelitian yang sejenis dengan hasil rata-rata yang saling mendekati ini maka diketahui apabila setiap terjadi peningkatan 1 tenaga kerja di sektor pertanian maka akan membuka kesempatan kerja sektor ekonomi lainnya sebanyak 1 sampai 2 tenaga kerja.

Penyerapan tenaga kerja sektor pertanian dari tahun 2011 ke 2012 terjadi penurunan sebesar 696 jiwa. hal ini disebabkan karena tenaga kerja baru lebih banyak terserap ke sektor industri dimana 
tahun 2011 sebesar 445 jiwa dan meningkat pada tahun 2012 menjadi sebesar 850 jiwa. Hal ini disebabkan oleh perubahan keadaan alam dimana keadaan air yang tidak sesuai dengan biasanya dan terjadi bencana banjir menyebabkan permasalahan dalam usaha perikanan dan usaha bertani padi sawah. Sektor pertanian merupakan sektor utama yang menyerap banyak tenaga kerja secara formal maupun informal. Namun sektor pertanian akan sangat sensitif terkena dampak perubahan iklim karena sektor pertanian bertumpu pada siklus air dan cuaca untuk menjaga produktivitasnya. Perhatian terbesar dampak perubahan iklim terhadap sektor pertanian adalah munculnya kekhawatiran akan kestabilan bahan pangan. Karena perubahan iklim menyebabkan kekeringan, penurunan air tanah, peningkatan suhu (pemanasan global), banjir, kekurangan kesuburan tanah, perubahan cuaca dan lain-lain yang beresiko gagal panen dan kelaparan (Agustin dan Inayati, 2015).

Pada tahun 2013 penyerapan tenaga kerja sektor pertanian mengalami peningkatan yang signifikan yaitu sebesar 3.885 jiwa dari jumlah sebesar 42.494 jiwa. Tenaga kerja kembali pada sektor pertanian diakibatkan tingkat pendidikan tenaga kerja masih tergolong rendah sehingga menyebabkan keterbatasan tenaga kerja untuk dapat bekerja pada sektor lain. Hal ini juga dikarenakan sektor pertanian merupakan lapangan kerja yang tidak memerlukan pendidikan formal melainkan dapat diperoleh dari pendidikan non formal dan pengalaman.

Tahun 2014 ke 2015 penyerapan tenaga kerja sektor pertanian terjadi penurunan yaitu sebesar 8.881 jiwa dari jumlah tenaga kerja 2014 sebesar 39.705 jiwa dan tahun 2015 sebesar 30.824 jiwa. Tenaga kerja sektor pertanian berpindah ke sektor industri dan sektor jasa. Salah satu penyebabnya adalah sebagian besar tenaga kerja tidak mampu bertahan pada sektor yang melalui waktu yang panjang dalam memperoleh hasil. Seperti sektor pertanian membutuhkan waktu yang lama untuk panen selain itu pada sektor pertanian terdapat berbagai resiko gagal panen.

Angka pertumbuhan tenaga kerja sektor pertanian $(\triangle \mathrm{NB})$ tertinggi terjadi pada tahun 2013 yaitu terjadi peningkatan tenaga kerja yang terserap di sektor pertanian sebanyak 3.885 jiwa, sedangkan terendah terjadi pada tahun 2015 yaitu terjadi penurunan sebesar 8881 jiwa.

Angka pertumbuhan tenaga kerja $(\Delta \mathrm{N})$ diperoleh dari hasil kali pengganda tenaga kerja $(\mathrm{k})$ dengan pertumbuhan tenaga kerja di sektor pertanian $(\Delta N B)$. Hasil analisis pertumbuhan tenaga kerja Kabupaten Barito Selatan selama tahun 2011-2015 diperoleh bahwa pertumbuhan tenaga kerja total tertinggi adalah pada tahun 2013 yaitu sebesar 5446 jiwa. Berdasarkan angka pertumbuhan tenaga kerja $(\Delta N)$ Kabupaten Barito Selatan menunjukkan bahwa pertumbuhan tenaga kerja sektor pertanian lebih dominan apabila dibandingkan dengan beberapaa sektor perekonomian yang ada. Pertumbuhan sektor pertanian di Kabupaten Barito Selatan melebihi 50\% dari total pertumbuhan tenaga kerja seluruh sektor, hal tersebut dapat dilihat pada Tabel 3.

\section{KESIMPULAN DAN SARAN}

\section{Kesimpulan}

Kesimpulan penelitian ini adalah sebagai bahwa sektor pertanian berdampak cukup besar terhadap penambahan tenaga kerja di seluruh sektor perekonomian di Kabupaten Barito Selatan. Hal tersebut diketahui berdasarkan angka pengganda tenaga kerja sebesar 1,6. Artinya, bahwa setiap terjadi penambahan 1 tenaga kerja sektor pertanian, maka akan membuka kesempatan kerja sektor ekonomi lainnya di Kabupaten Barito Selatan sebanyak 1 sampai 2 tenaga kerja.

\section{DAFTAR PUSTAKA}

Agustin, G. dan Inayati, R. (2015). Analisis Perubahan Iklim Bagi 
Pertanian di Indonesia. JESP 7 (2): 85-89.

Badan Pusat Statistik Kabupaten Barito Selatan. (2013). Kabupaten Barito Selatan Dalam Angka Tahun 2012. Buntok: BPS Barito Selatan. . (2014). Kabupaten Barito Selatan Dalam Angka Tahun 2013. Buntok: BPS Barito Selatan. - (2015). Kabupaten Barito

Selatan Dalam Angka Tahun 2014. Buntok: BPS Barito Selatan. . (2016). Kabupaten Barito Selatan Dalam Angka Tahun 2015. Buntok: BPS Barito Selatan.

Badan Pusat Statistik Provinsi Kalimantan Tengah. (2013). Statistik Ketenagakerjaan 2012. Palangka Raya: BPS Kalimantan Tengah. (2014)

Statistik Ketenagakerjaan 2013. Palangka Raya: BPS Kalimantan Tengah. (2015). Statistik Ketenagakerjaan 2014. Palangka Raya: BPS Kalimantan Tengah.

(2016).

Statistik Ketenagakerjaan Tahun 2015. Palangka Raya: BPS Kalimantan Tengah. Budiharsono, S. (2005). Teknik Analisis Pembangunan Wilayah Pesisir Dan Lautan. Jakarta: Pradnya Paramita.

Khaafidh, M. (2013). Faktor-Faktor yang Mempengaruhi Keputusan Tenaga Kerja untuk Bekerja di Kegiatan Pertanian (Studi Kasus: Kabupaten Rembang). Skripsi. Fakultas Ekonomi dan Bisnis Universitas Diponegoro. Semarang.

Kurniawan, A. (2008). Peranan Sektor Pertanian dalam Penyerapan Tenaga Kerja di Kabupaten Temanggung. Skripsi. Fakultas
Pertanian Universitas Sebelas Maret. Surakarta.

Luthfi, M. K. (2017). Peran Sektor Pertanian terhadap Penyerapan Tenaga Kerja dan Distribusi Pendapatan di Kabupaten Klaten. Skripsi. Fakultas Pertanian Universitas Sebelas Maret. Surakarta.

Nugroho, F. A. (2015). Peranan Sektor Pertanian dalam Penyerapan Tenaga Kerja di Kabupaten Kebumen. Skripsi. Fakultas Pertanian Universitas Sebelas Maret. Surakarta.

Rozi, T. F., Sofyan, Marsudi, E. (2017). Peranan Sektor Pertanian dalam Penyerapan Tenga Kerja di Provinsi Aceh. Jurnal Ilmiah Mahasiswa Pertanian Unsyiah 2 (2).

Safangatun, F. I. (2011). Peranan Sektor Pertanian dalam Penyerapan Tenaga Kerja di Kabupaten Cilacap. Skripsi. Fakultas Pertanian Universitas Sebelas Maret. Surakarta.

Safira, E. (2017). Analisis Peranan Sektor Pertanian dalam Penyerapan Tenaga Kerja di Kabupaten Sukoharjo. Skripsi. Fakultas Pertanian Universitas Sebelas Maret. Surakarta.

Sulistiawati, R. (2012). Pengaruh Upah Minimum Terhadap Penyerapan Tenaga Kerja dan Kesejahteraan Masyarakat di Provinsi di Indonesia. Jurnal EKSOS 8 (3): 195 -211 .

Wicaksono, R. 2010. Analisis Pengaruh PDB Sektor Industri, Upah Riil, Suku Bunga Riil, dan Jumlah Unit Usaha terhadap Penyerapan Tenga Kerja pada Industri Pengolahan Sedang dan Besar di Indonesia Tahun 1990 - 2008. Skripsi. Fakultas Pertanian Universitas Diponegoro. Semarang. 